\title{
Facies Changes Between Kolosh and Sinjar Formations Along Zagros Fold-Thrust Belt in Iraqi Kurdistan Region
}

\author{
Kamal Haji Karim Ahmad ${ }^{1}$ \\ ${ }^{1}$ Department of Geology, university of Sulaimani, Kurdistan region, Iraq \\ Correspondence: Kamal Haji Karim, Department of Geology, University of Sulaimani, Sulaimani city, Kurdistan \\ Region, Iraq. Tel: +9647701571445, E-mail: karimgeology@yahoo.com
}

Received: October 16, 2015

Accepted: November 4, 2015

Online Published: November 29, 2015

doi:10.5539/jgg.v8n1p1

URL: http://dx.doi.org/10.5539/jgg.v8n1p1

\begin{abstract}
The present study is concerned with lateral and vertical facies changes between Kolosh (Paleocene) and Sinjar (or Khurmala) (Paleocene-Early Eocene) Formations in Sulaimani and Duhok area, Kurdistan Region, NE-Iraq. The latter and former formations are belonging to basinal clastic (turbidite) and reefal carbonate facies respectively. The facies changes are documented in six sections by field studies and evaluation of previous ideas and data which are critically discussed and compared to the result of the present study. The special attention is directed towards the contact between the two Formations in relation to conformity. All the studies achieved before 2002 showed conformable contact between the two formations while the most recent study found large a gap (erosional unconformity) between the two formations which persisted for 5 million years. According to latter study, the sea level fall associated with this unconformity assigned to be type one and type two sequence boundaries in the east of Darbandikhan, north of Koya towns and the Bekhme gorge.

Conversely, the present study has not recorded gaps in the sedimentation in the studied sections either in Sulaimani or Dohuk area. The contact can be regarded as transgressive system tract which represented by green marl or sandstone, which changes to limestone of Sinjar or Khurmala Formation (HST).The conglomerate beds that are recorded in the previous studies at the contact of the two formations are not proved in the present study. The previously recorded conglomerate is located inside the upper part of the Kolosh Formation not in the contact and it represents submarine fan feeder channel. In contrast to previous studies, neither incised valleys nor erosional unconformity are found at the contact between the two formations in the studied area. The one meter intraformational conglomerate that are found (in some previous studies) in the Bekhme gore is not found in the present study. It is observed that the Kolosh Formation, at Bekhme Gore consists of green marl and sandstone with one bed of Khurmala Formation. The green marl is changes totally to dolomitic limestone of the latter Formation toward northwest at the north of Saru Kani village near Bujeel town. This proves that both formations are deposited in one basin and Khurmala formation has the age of Lower Paleocene to Lower Eocene.
\end{abstract}

Keywords: Kolosh Formation, Sinjar Formation, Khurmal Formation, facies changes, Zagros Fold-Thrust belt, Kurdistan stratigraphy, Kurdistan sedimentology, Iraq geology

\section{Introduction}

The Kolosh Formation was firstly described by Dunnington (1952; in Bellen et al., 1959) in Kalozh area north of Koya town, northern Iraq (Fig.1). It consists of alternation of medium to thin beds of calcareous shale and sandstone which contain fragments of various grain sizes of igneous, chert and radiolarite. They added that its age extended from Paleocene to lower Eocene, while Al-Omari et al. (1993) and Al-Mutwali (2001) reported early Paleocene-Early Eocene age to Kolosh Formation near Shaqlawa town, north Iraq. Al-Mutwali and Al-Wazan (2010) recorded Early-late Paleocene age to Kolosh succession in Duhok area.

According to Bellen et al., (1959) and Jassim and Goff, (2006), the Paleocene Kolosh Formation is deposited as flysch facies of sandstones, marls, shales, intraformational conglomerates and thin beds of arenaceous limestone. They added that it is deposited in subduction trench, parallel to the suture zone that is formed by closing of the southern Neotethys Ocean and final collision between the Arabian, and Iranian plates. According to Bellen, (1959), Kolosh Formation is coeval with several other formations in other parts of Iraq. They added that these formations are diachronous and defined according to lithology. In north Iraq, it is passing to or inter-tongue with 
algal reef limestone (Sinjar Formation) and reef - back reef deposit (Khurmala Formation).

Sinjar (Eocene) Formation is outcropping in Sulaimani and Dohuk area as a narrow belt in the boundary between High and Low Folded Zones (Fig.1). Its temporal and spatial lagoonal equivalent is Khurmala Formation. Sinjar Formation is mainly exposed near the summit of Sartak-Bamo, Tasluja, Baranan (Glazarda), Berke, Haibat Sultan, Pirat (its southwestern limb) and Bekher Mountains. It has thickness 20- 130 meters and composed of thick, massive or well bedded highly fossiliferous limestone with occasional beds dolomitic limestone.

The underlying unit is Kolosh Formation and their contact assigned as gradational by Bellen et al, 1959; Al-Shaikh et al, 1975, p.59; Jassim et al.,1975, p.144; Buday, 1980; Surdashy, 1989, p.163; Surdashy and Lawa, 1993, p.78; Karim, 1997. In contrast to the above authors, recently Lawa (2004, 2008), Lawa et al. (2013) and Jaff (2008) have discussed the unconformable contact between Kolosh and Sinjar Formation (K-S contact) in some parts of Sulaimani area. They found incised valley at their contact at the Darbandikhan and Dokan area and claimed that there is a gap in sedimentation lasted 5milion years (the whole Yapressian age). They added that this unconformity is type one and type two sequence boundaries at different areas.

\subsection{Method of the Study}

The present study based on studding 6 sections which are distributed along outcrops of the two formations near the boundary between High and Low Folded Zone in Sulaimani and Dohuk governorates. The inspected outcrops are elongated, near Iranian border at the southeast of Darbandikhan town to northwest near Turkey border. The area has the length of more than $300 \mathrm{~km}$ along which the contact of Kolosh and Sinjar or Khurmala Formations (K-S contact) is well exposed (Fig.1). The sections, from extreme southeast to northwest, are 1-Zhalla, 2-Bamo, 3-Dara Rash, 4-Kalozh, 5- Bekhme and 6-Saru Kani (Bujel) sections. In addition to visual inspection, the lithological details of the sections are reviled by using hand lens $10 \mathrm{X}$ and polarized microscopes for inspection of hand specimens and thin sections respectively. According to the field and lab studies, the previous studies are analyzed and critically compared to the result of the present study.

\section{Result}

\subsection{Previous Controversy}

Karim (1997), Ghafoor and Karim, (1999. p.493) have studied the Sartak-Bamo valley lithologically and biostratigraphically and recorded gradational contact between the two formations. They showed that the thin beds of Nummulite bearing limestone, inside Kolosh Formation, thicken upward and finally change to Sinjar Formation on expense of green marl (Fig.2 and 3). The same gradation is present in Duhok area which is observed in the present study but Al-Banna et al. (2012) have recorded one meter of intraformational conglomerate between the two formations at the outlet of Bekhme gorge. They have mentioned that the conglomerate was contained boulder of $25 \mathrm{~cm}$ diameters. While Lawa (2004, p.67, 103, 235) studied the sections of Sartag-Bamo Gorge and Zhalla section (in the Sartak valley) and inferred a major gap and unconformity which lasted 5million years between the two formations. Jaff (2008) has recorded same unconformity at Kalozh and Kalka Smaq areas and mentioned that it represented by 1 meter conglomerate which deposited inside incised valley.

By the major gap, Lawa (op cit) meant the subaerial erosion as he mentioned in page 199 and 226 "Bamo area remained above sea level during Ypresian". Additionally, he had recorded 3.5 to $5 \mathrm{~m}$ conglomerate bed between the two formations which filled the incised valley. In his tectonic model in the page 232, he extended the unconformity to the distal part of the basin. He mentioned in page 186 that he had recognized well-presented and developed incised valley in Bamo and Zhalla sections. 


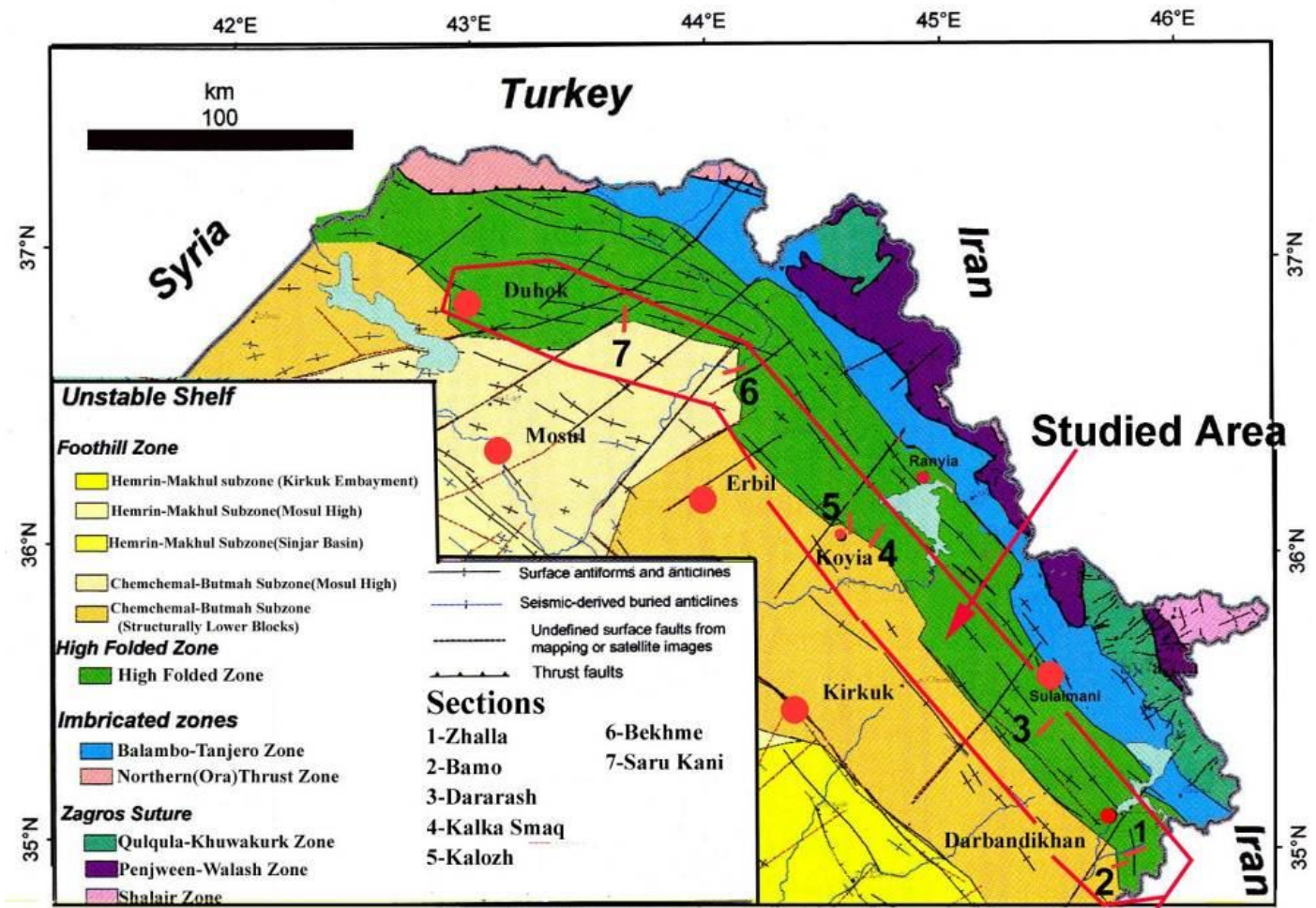

Figure 1. The tectonic map of Northern Iraq (Jassim and Goff (2006) on which the location of the studied sections are shown

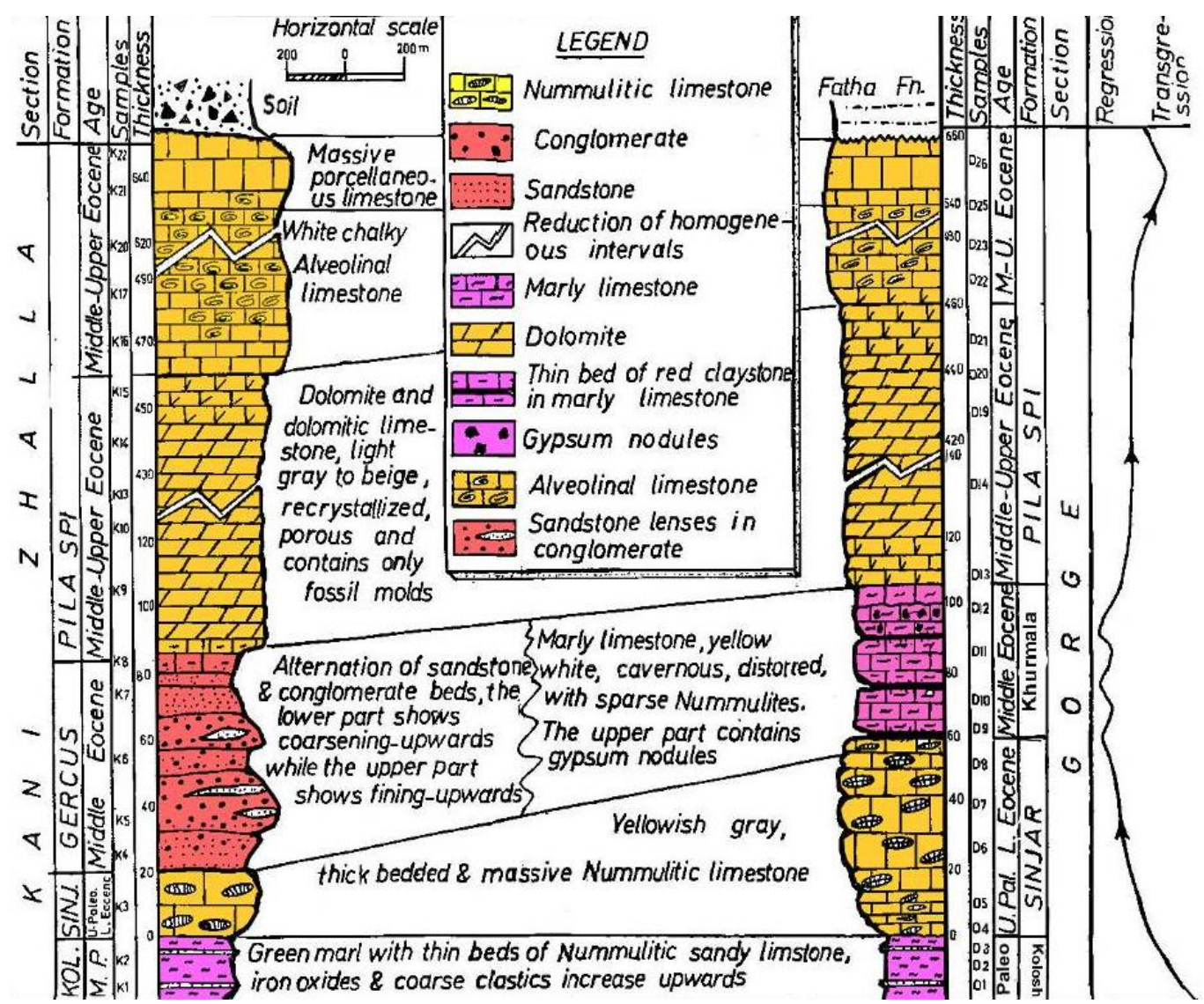

Figure 2. The two stratigraphic column of the Sartak-Bamo area (Karim, 1997) 

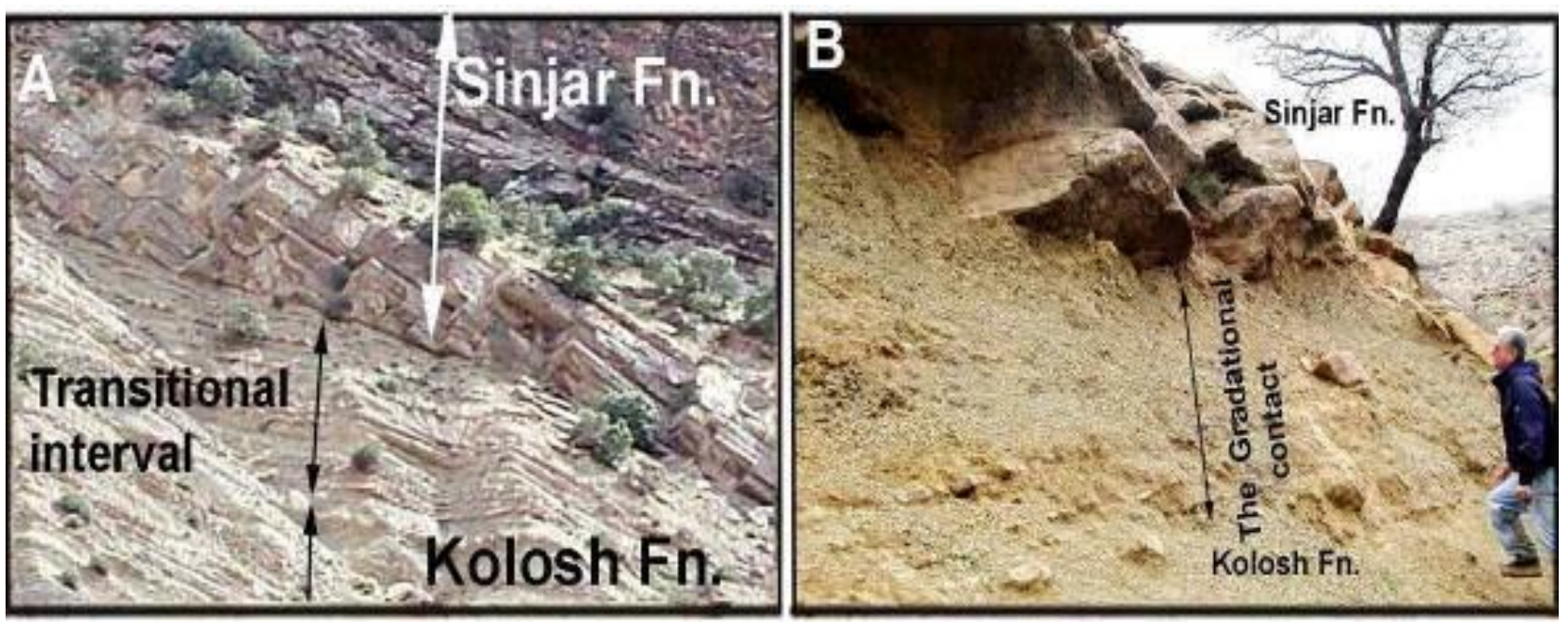

Figure 3. Two outcrop sections of the contact between Kolosh and Khurmala formations in Sartak-Bamo valley show gradational relation, A) Bamo section, $1.5 \mathrm{~km}$ south of Sartak village, B) Sartak section $300 \mathrm{~m}$ to north of Sartak village

\subsection{Field Judgment}

In addition of the Sulaimani Governorate sections, two additional sections are taken in Dohuk areas (Bekhme and Saru Kani section) (Fig.4 and 5). These sections are taken to ending the controversy of the conformable or unconformable contact between the two formations. In the Bekhme section three important field observations can be recorded, the first is that Sinjar and Kolosh Formations are about 20 and 70 meters thick respectively. In this area, the latter formation consists of highly deformed dark green to grey marl and sandstone. Toward the northwest, the green marl changes totally to dolomitic limestone of Khurmala Formation in the area around Bujel town and directly underlain by Aqra Formation (Figure 5). The second observation is that neither conglomerate nor erosional surface is found inside both formations or at their contact. The third is that the facies change from green marl to dolomitic limestone is gradual and passes through intermediate facies which is marly limestone.

Similarly, the vertical facies change, as mentioned before, is also gradational and the marl and sandstone (of Kolosh Formation) is change to pure limestone of Sinjar (or Khurmal) Formation passing through transitional zone. This zone consists of a mixture of the three lithologies (Figure 6,7 and 8). This is true for the sections that are located in the Duhok and Sulaimani Governorates.

According to the above three points, it is clear that there is no any observable unconformity either at the contact or inside the two formations. The lateral facies change between the two formations is the strongest evidence for the absence of the unconformity. The lateral change is evidence for sharing one large basin in which the two and Aliji formations are deposited concurrently.

But this does not mean that there was no unconformity in the near shore area of the Tertiary foreland basin since the basin was bounded by terrestrial land from north and northeast. Karim (2010) and Karim, et al. (2011), had shown for the first time many unconformities in the coastal area of the Zagros Foreland Basin (Present Thrust Zone).However, the location of the sections of the present and of all previous studies were far from the coastal area for more than $35 \mathrm{~km}$, therefore, in this latter sections, the unconformity that is cited by Lawa and Jaff (2008) and Lawa, 2013 in Sulaimani area is difficult to be accepted by this paper. The present study does not refuse the correlative conformities for the coastal unconformities which may be represented by sand stone or shale.

In the Sartak-Bamo valley and Zarayin area the contact is gradational too in the two studied sections and there are no any conglomerates or other lithologies to indicate the unconformity (Fig.3 and 6). The lithology in these sections showing shallowing upward succession manifested by alternation of calcareous sandstone (with reworked nummulites) and shale within the upper part of Kolosh Formation which changes to alternation of limestone with shale at the contact between the two formation then change to massive limestone of Sinjar Formation. 


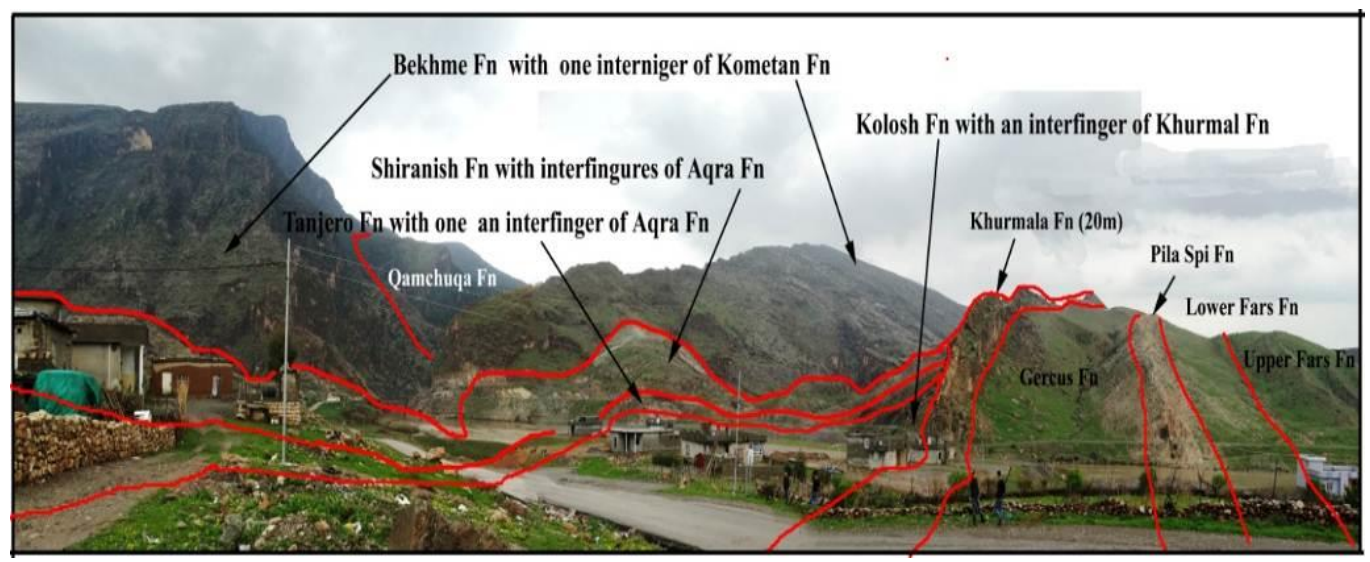

Figure 4. Differentiation of the formations of the outlet of the Bekhme Gorge

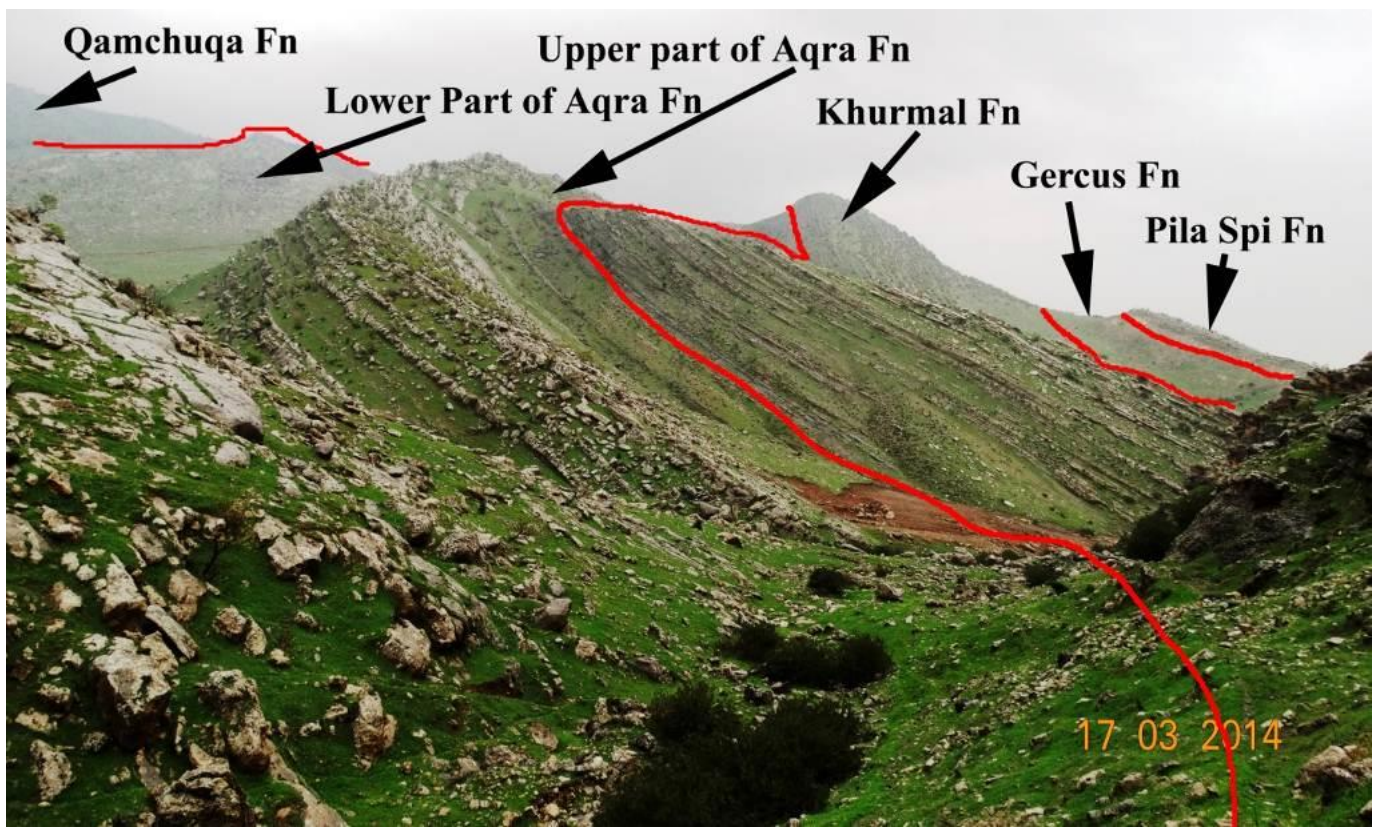

Figure 5. Photo of the outcrop of the Saru Kani shows that there is no Kolosh Formation and it changed totally to Khurmal Formation

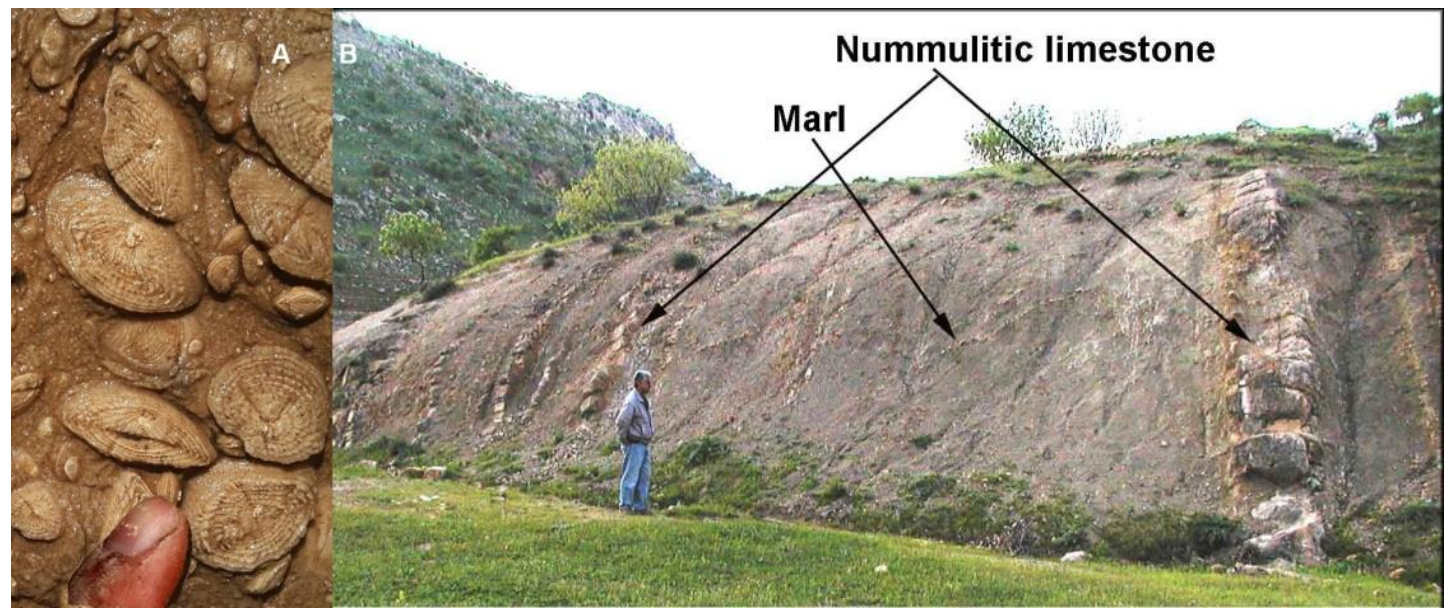

Figure 6. A) Nummulies in the lower part of Sinjar FormatioQaradagh area, B) The gradational boundary between Kolosh Formation and Sinjar Formation between Kashty and Birke village, Zarayn area 
Only the Zhalla section shows two lenses of conglomerate inside the Kolosh Formation. One of the lenses located at the $50 \mathrm{~m}$ below the contact and the other one located 2-3m below the contact (Fig.7A). Even one of the photos given by Lawa (2004, in the plate 12, fig.1, in the appendix of his thesis on the CD) shows clearly the conglomerate inside the Kolosh Formation while Sinjar limestone is appeared far away at the background. The thickness of these lenses is about $1-1.5 \mathrm{~m}$ and disappears at the distance of, at least, $50 \mathrm{~m}$. Lawa (op. cit) regarded these lenses as the sediment of incised valleys. While, in Haibat Sultan mountain, Al-Qayim and Nisan (1989, p.444 and 531) have recorded three lenses of conglomerated inside Kolosh Formation and interpreted them as prograding of submarine turbidite channels. They assumed them as transitional facies between deep marine sediment of Kolosh Formation and shallow carbonate of Khurmala Formation (lagoonal equivalent of Sinjar Formation). Therefore, the latter authors clearly pointed to conformable contact between the two formations (see the Al-Qayim, 1994, p.350). The same thing is recorded by Surdashy and Lawa (1993, p.78) in Sulaimani area which mentioned that gradational contact marked by first appearance of fossiliferous carbonate beds above the green marl clastic sequences.

Along the clear road cut at $1 \mathrm{~km}$ southwest of Kalka Smaq village (Dokan area) (Fig.7C), the contact shows clear alternation of the lithology which is similar to that of Sartak-Bamo valley and Dararash sections. In the area of the village, and below the contact there are two lenses of conglomerate. These two lenses are located inside Kolosh Formation and indicated neither erosional gap nor break which is similar to condition of Zhalla section in Sartak-Bamo valley.

It is possible that Lawa (2004 and 2008 and Jaff, 2008) and Lawa, et al 2013 had indicted the major and minor unconformity on the basis of disappearance of planktonic and benthonic forams. If it was the method, it is not always true because both type are more or less sensitive to environment of deposition especially influx of terrigeneous clastic which generated turbidity current. These currents most possibly damaged the organism or caused lack of nutrient in the water and forced them to migrate without break in sedimentation. It is possible that the sedimentation is increased not stopped or eroded. This may be the case that had happened in the whole distal area of the occurrence of the two formations.

On page 175, Figure 5-4, of the PhD thesis of Lawa (2004), about 100m of Sinjar Formation is showed to be deposited during Ypresian (8 M.y) in the Kani Gopala, Sagerma, and Darbandikhan sections. The important of this $100 \mathrm{~m}$ of Lawa (Ibid) is that it is associated with Bouma division of turbidite which may be occurred too in Zhalla and Bamo sections which may be suffered from more clastic influx and more sediment by pass than former section of the right side of Sirwan (Diala) river. In the present author's judgment, sedimentation of the upper part of Kolosh Formation in the latter two sections is increased instead of stopping but the fine fraction is reworked to deeper part of the basin.

According to Reynolds (1994, in Emery and Myers 1996, p.138 and 140) the incised valley has thickness to width ratio of 1:1000 while that of channel is 1:100. According to this, the conglomerate lenses that occur in the Kolosh Formation have the prerequisite of submarine channel rather than incised valley as interpreted by Lawa (2004).
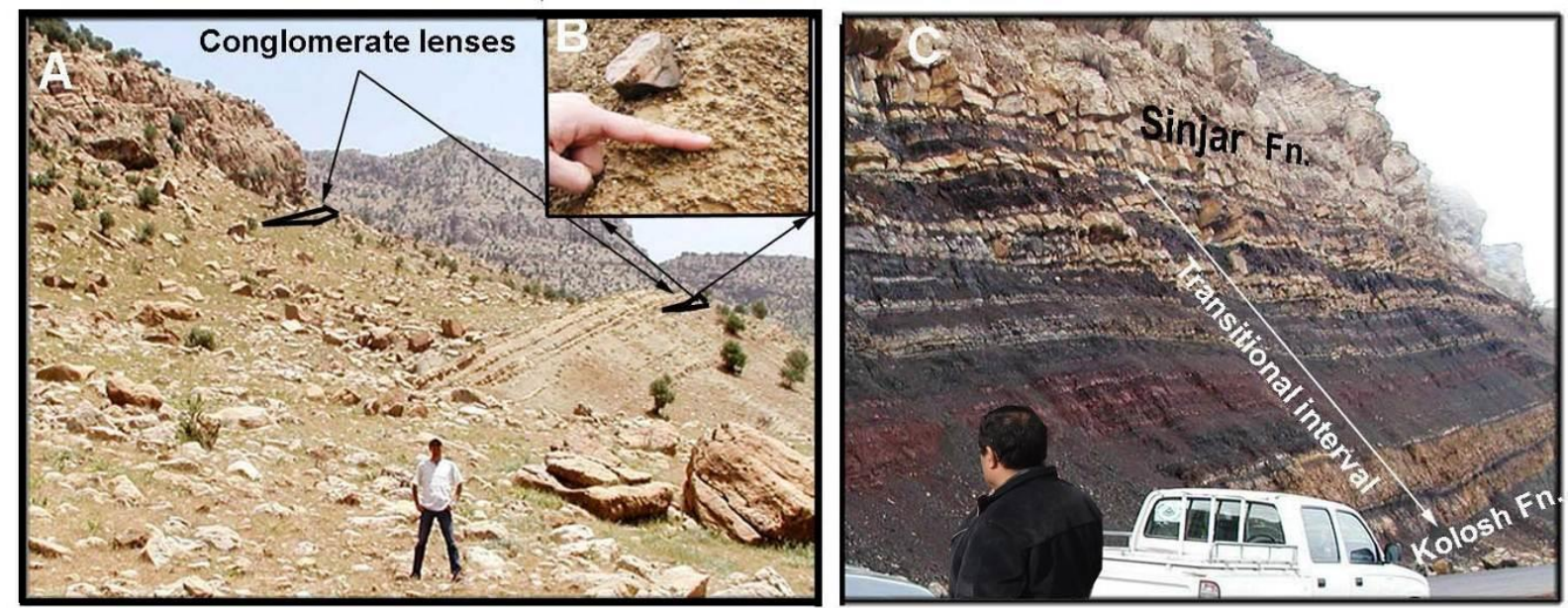

Figure 7. A) Zhalla (or Kani Zhalla) section which shows two lenses of conglomerate inside Kolosh Formation, B) the close up photo of the conglomerate at 30 meter below the contact. C) Clear gradational contact between Kolosh and Sinjar Formation along road cut at $1 \mathrm{~km}$ west of Smaqully village, Dokan area 


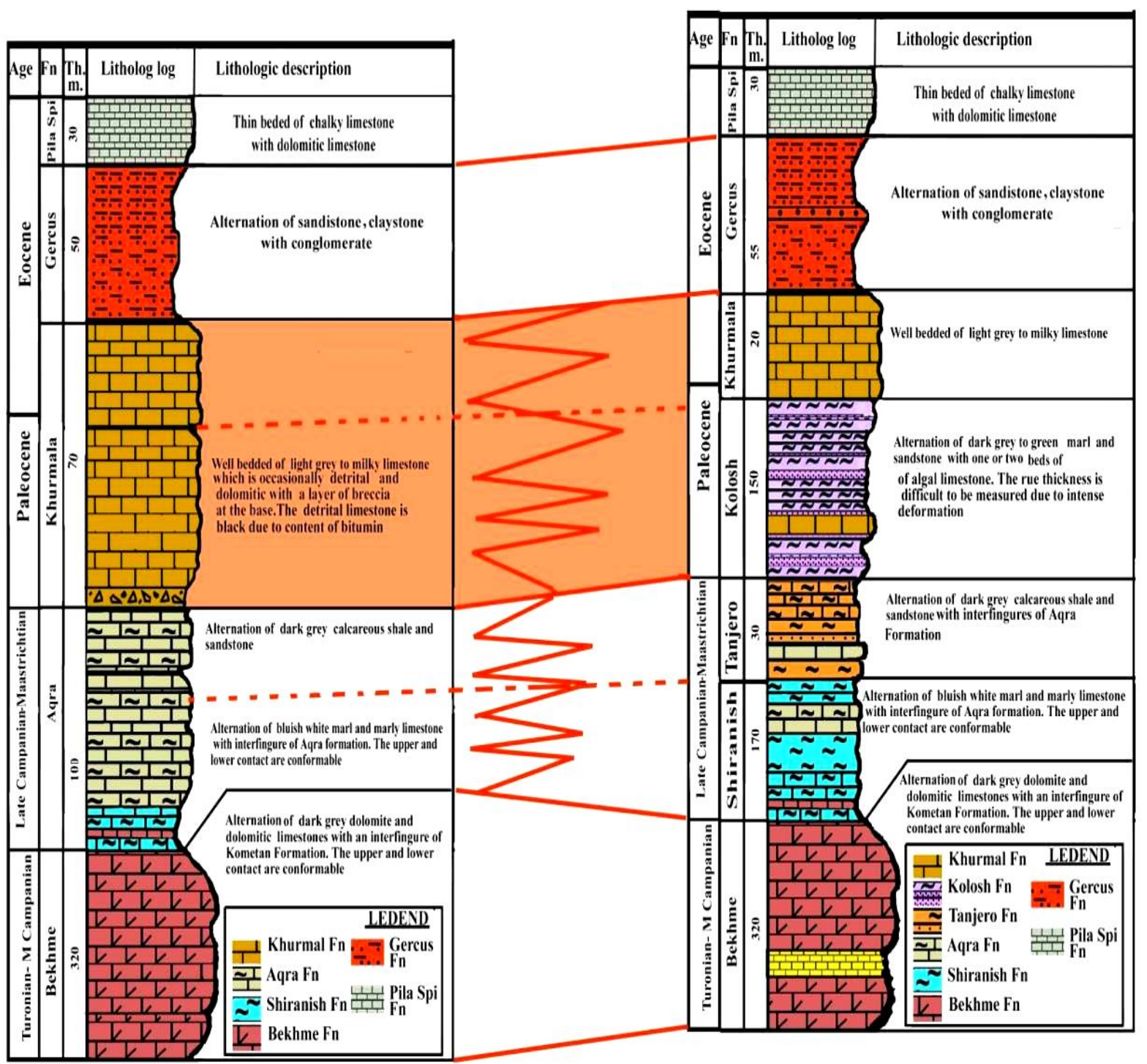

Figure 8. A lithostratigraphic correlation of Bekhme and Saru Kani sections which shows the lateral and vertical facies change of Kolosh (green marl) to Khurmala formation

\section{Discussion}

\subsection{The Position and Amplitude of the Sea Level Change of the Contact}

Unfortunately the result of sequence stratigraphy, included in the study of Lawa, (2004) and Jaff (2008) is not clear as they doesn't plot the stratigraphy of the area on the Wheeler diagram. Lawa (2004) in the page 183 has drawn the stratigraphic column of both Zhalla and Bamo sections and in these sections; he indicated the contact between Kolosh and Sinjar Formations 13 meters below the contact that concluded in the present study (Fig.9 see red arrow). He indicated the contact below the conglomerate which is assigned, in the present study, as part of Kolosh Formation.

Jaff (2008) discussed that the contact between Kolosh and Khurmala Formations is a type one sequence boundary in both Smaqully and Kaka Smaq areas and he mentioned that it is represented by incised valley and in which one meter conglomerate was deposited. He showed the stratigraphic position of the conglomerate inside green marl (Fig.10). This conglomerate is inspected in the present study and inferred that it is a diagenetic structures which are consist of limestone clasts in the size of gravels and embedded in green marl. The clasts have smooth and wavy surfaces with mammillary lobes.

The clasts are not associated with terrigenous grains of sand and gravel sizes. Most probably, the clasts are formed by deposition of carbonate thin layers between green marl ones. In some place, the trace of bedding can 
be seen (Fig.11). During burial the layers are deformed by breakage and intrusion of soft marls into fractures and the final result was the generation of apparent limestone conglomerate-like rock. This diagenetic process is discussed in detail by Karim (2006) in the Kolosh and Tanjero Formation in detail.

The recognition of actual position and amplitude of the sea level change depend on the inferred position of paleoshore line (or distal and proximal area of the Paleocene basin). By the position of sea level change, the present author mean the position of the studied outcrop relative to shore line in the Foreland basin where the sea level change can be seen obviously and studied. By amplitude, he means the magnitude of the sea level change as indicated by SB1 and SB2 (or as measured by meters).

The geographic position of shore line of Kolosh Formation is indicate by Lawa (2004, p.172) as a nearly straight line that is passing from $2 \mathrm{~km}$ south of Dokan town to $2 \mathrm{~km}$ north of Zarain town then bends to the south and pass through Shameran village to about $2 \mathrm{~km}$ to the north of Sartak-Bamo area. This shore line is indicated by him for Selandian age (Middle Paleocene) which assumed by him as either TST or HST in the stratigraphic columns in the chapter of sequence stratigraphy. This means that the inferred shore line of the formation, during LST, was more southward which, at least, reached the position of the studied sections. According, his studied sections are located in the proximal area (near shore area) during LST deposition. Therefore the lenses of the conglomerate of Lawa (Ibid) cannot be assigned as incised valley or SB1. Because it is normal for the near shore area to contain more or less lenses of conglomerate during all type of sea level change.

Basin of Paleocene and Eocene in addition to Tanjero basin, is called "Zagros Early foreland basin" by Karim (2004, p.6), while Baziany (2014) named this basin as Tertiary Zagros Foreland basin and the basin of Shiranish and Tanjero Formations as Cretaceous Zagros Foreland basin. The shore line of Lawa (2004) during Middle Paleocene is not considered in the present study. Karim and Ali (2004, p.7 and 16) have estimated the shoreline during above age to be at southern limb of Azmir anticline during Paleocene- Eocene. Very recent study by Barzinjy (2005) indicated; in this study of Red Bed Series, the shoreline 20km more northwestern ward than that indicated by Lawa (2004). According to the former author the shoreline line was at the south of Chwarta, Mawat and Khurmal towns during HST.This later estimation agrees with the fact inferred by Karim (2004) and Karim and Surdashy (2005, p.14) for the basin of Tanjero Formation. They found that the distance between proximal and distal area of Tanjero basin was more than $30 \mathrm{~km}$ during Maastrichtian.

According to these facts, all sections studied by Lawa (2004) and Jaff (2008) are inferred in the present study to be located at distal area of Paleocene basin and the contact between the two formation is gradational (conformable). In sequence stratigraphy, the contact, being mostly represented by marl or sand, most possibly deposited during TST and Sinjar Formation deposited during HST. The conglomerate lenses located below the contact (inside Kolosh Formation) is indicated a short duration of event in upper part of Kolosh formation. It is possible that this event might be change, up dip of the paleoslope, to unconformable nature at the near shore area which might be manifested by SB2 only.

In some place, in Duhok area, the Khurmala Formation was deposited during both LST and HST due to the fact that the area was far from turbidity due to location on a submerged paleohigh. On this high the Khurmala Formation is deposited as concurrent and lateral facies change of the Kolosh Formation. This is shown in the two models (figure 12 and 13) in which it can be seen that the carbonate sedimentation was continuous from the Early Cretaceous till the end of the Paleocene without major unconformities. The geology of the Duhok area during Cretaceous with paleogeographic setting is discussed in detail and modeled graphically by Karim (2013) as shown in the latter two figures.

Recently, Khanaqa and Karim (2015) have observed that Gercus Formation (on the northeasttern limb of Sagrma anticline) is change to Khurmala Formation on the southertern limb. This means that on the latter limb the Khurmala is located between Pila Spi (Middle-Upper Eocene) and Sinjar Formations (Middle-Lower Eocene). This stratigraphic position of Khurmala Formation nearly agrees the definintion of Bellen et al. (1959) at its type section is located between Avanah Formation (Middle- Upper Eocene) and Kolosh Formation (Paleocene). 


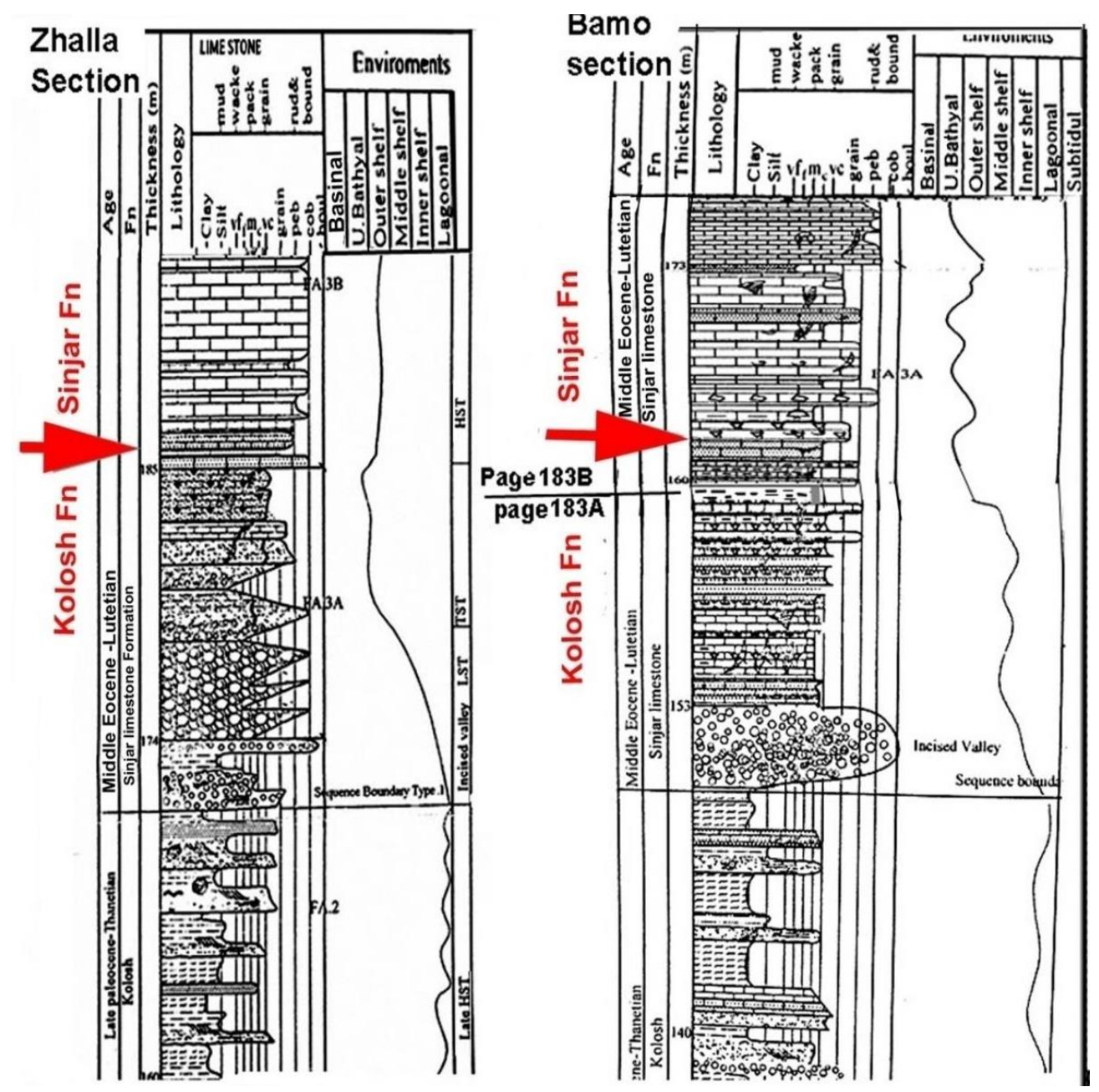

Figure 9. Selected part of the Zhalla and Bamo sections as drawn by Lawa (2004) on which the contact between Kolosh and Sinjar Formation of the present study is indicated by red arrow. According to this new boundary the conglomerate is located inside former formation

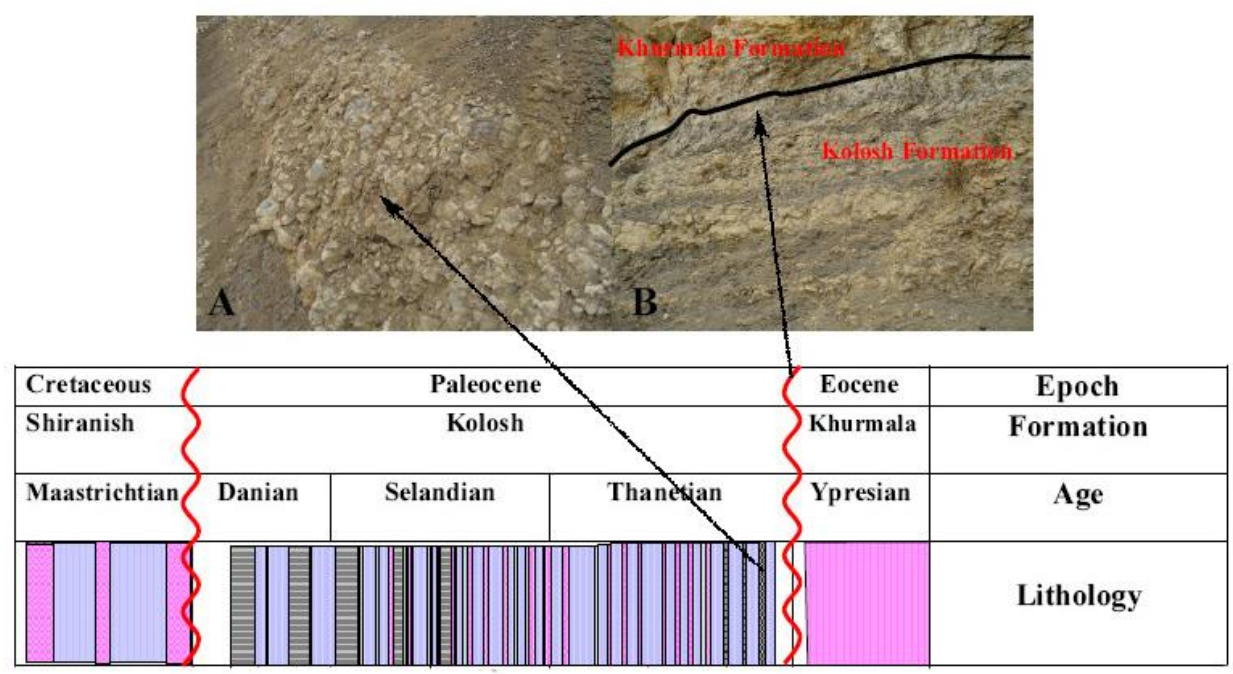

\section{Legend/}
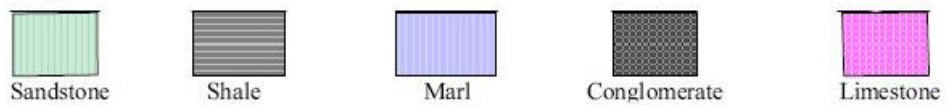

\section{MWN}

Unconformity

Figure 10. Stratigraphic position and photo of the conglomerate that is recorded by Jaff (2008) it can be seen that conglomerate is located inside marl 


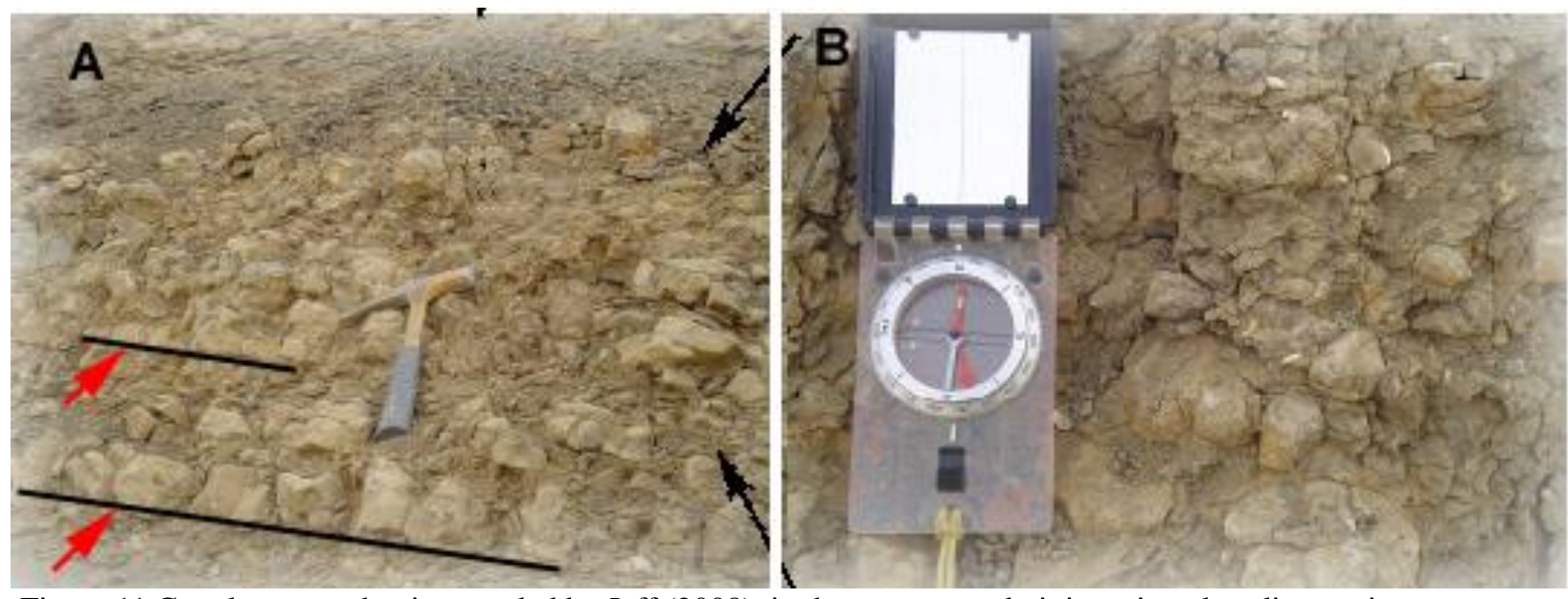

Figure 11.Conglomerate that is recorded by Jaff (2008), in the present study it is assigned as diagenetic structure since the trace of bedding can be seen (red arrows)

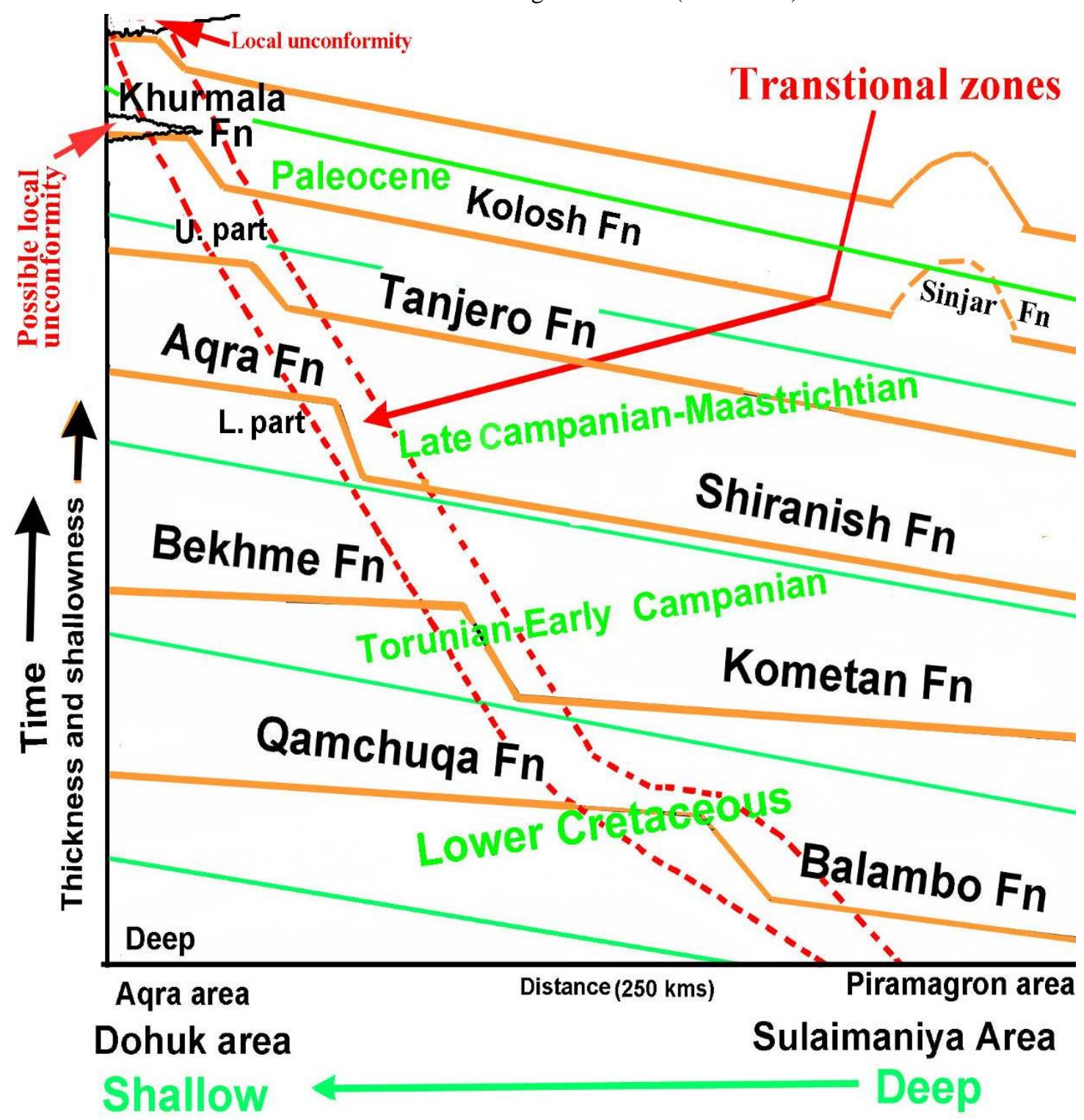

Figure 12. Graphical model for the deposition of lateral facies change of the Cretaceous and Paleocene formations in Sulaimani and Duhok Governorates (Modified from Karim, 2013) 


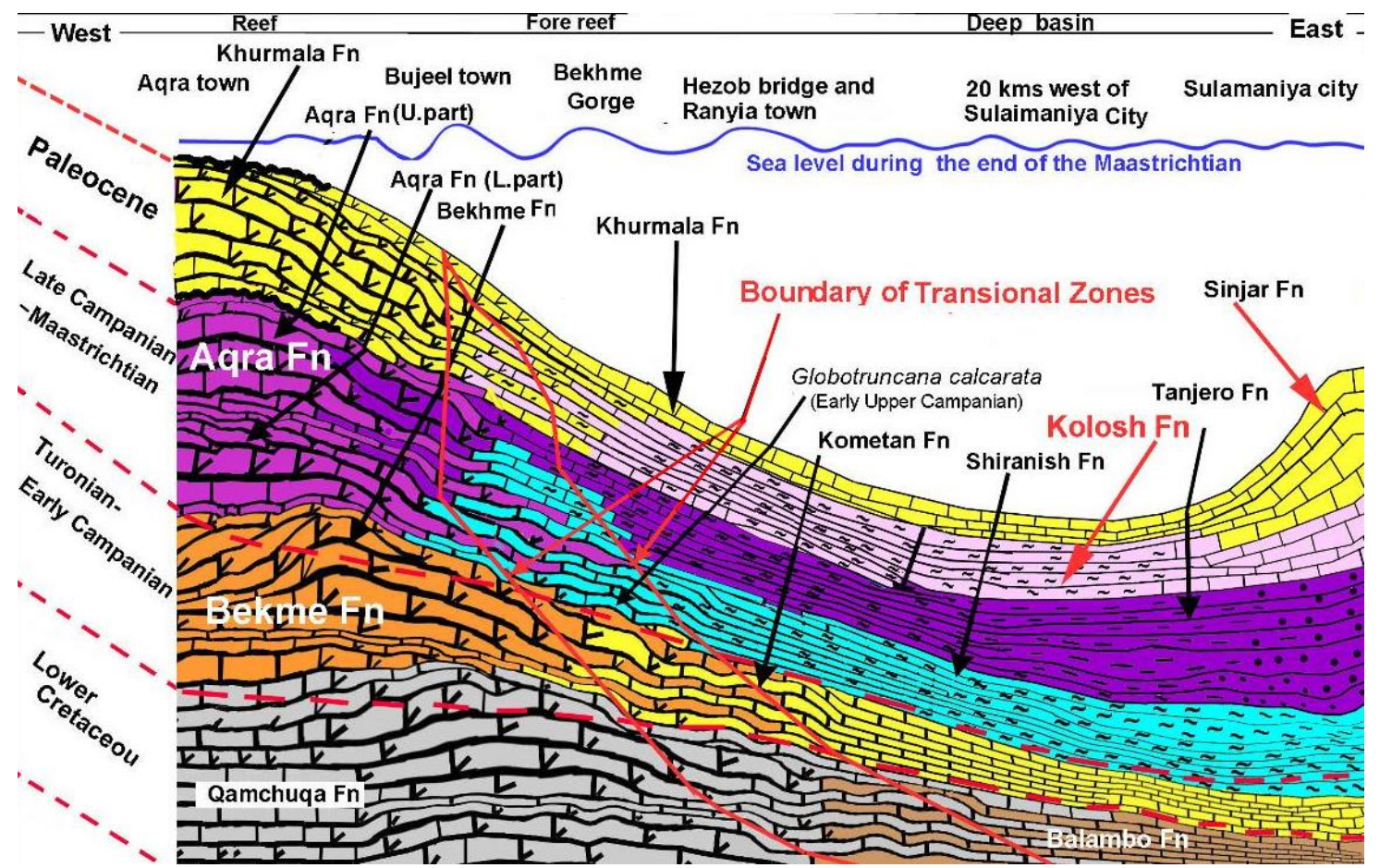

Figure 13. Lateral Facies change of the Cretaceous and Paleocene formations in Sulaimani and Duhok Governorates (Modified from Karim, 2013). It can be seen that Kolosh Formation change totally to Khurmal Formation near Aqra town

\subsection{Northward Facies Change of Sijnar Formation}

The northward (toward Iranian border) lateral facies change of Kolosh Formation is well documented by Barzinjy (2005) and Karim et al (2007) whom stated that the formation changes to Red Bed Series toward the north. They inferred that both units deposited concurrently in the Early Zagros Foreland Basin as distal and proximal facies changes. Conversely, the northwest facies of Sinjar (or Khurmala) Formation is not yet treated. It is not known, exactly, what is the equivalent (in aged and basin) of Sinjar Formation in the Thrust and Imbricated Zone (for example in the Chwarta and Mawat area). Karim et al. (2008) referred to probability of being Sinjar Formation is equivalent to a part of Red Bed Series but without indicating that part of the series. The northwest facies change of Sinjar Formation is not the topic of the present study but it will be treated in the present author future paper.

\section{Conclusions}

The paper has the following conclusions:

1-The contact between Kolosh and Sinjar (or Khurmala) Formations are gradational in all section located in Sulaimani and Dohuk areas. This gradational contact changed to the minor unconformity at the proximal area (near shore area).

2- Instead of unconformity (erosion or non- deposition), the sedimentation is increased near the contact between the two formations.

3 - In sequence stratigraphy, the contact, at the studied sections, represent the correlative conformity boundary which is equivalent to sequence boundary of type 2 in the coastal area.

3-In Dohuk area the Kolosh Formation is change totally to Khurmal Formation

4-Where there is continuity of clastic sedimentation, the paleontologic study cannot be used as criteria for indication of the position and duration of unconformity.

\section{References}

Al-Qayim, B. (1994). Evolution of flysch basin along the Northeastern margin of the Arabian plate. Proceeding of the $5^{\text {th }}$ Jordania Geological Conference on the Geology of the Middle East (Geocome 3), 347-372.

Al-Qayim, B., \& Nisan, B. (1989). Sedimentary facies analysis of Paleogene mixed carbonate clastic sequence, 
Haibat-Sultan Ridge, NE-Iraq. Iraqi Jour. Sci., 30(4), 525-557.

Al-Shaikh, Z. D., Saleh, S. A., \& Abdu, H. F. (1975). Contribution to the geology of Shaqlawa-Hareer area, Iraqi Geol. Soc. (Special issue), 55-67.

Barzinjy, S. T. (2005). Stratigraphy and basin analysis of Red Bed Series in Sulaimaniya area, NE- Iraq (Unpublished master thesis), University of Sulaimani.245p.

Baziani, M.M. (2014). Depositional systems and sedimentary basin analysis of the Qulqula Radiolarian Formation, of The Zagros Suture Zone, Sulaimani Area, Iraqi Kurdistan Region (Unpublished doctoral dissertation), University of Sulaimani, Kurdistan region, Iraq.

Bellen, K. C., van Dannington, H. V.,Wetzel, R., \& Wortone, D. M. (1959). Lexique Stratigraphic International; Vo.3, Asie, Paris, Internat. Geo. Cong., Coniim. Stratig., Pt, 10, 333p.

Buday, T. (1980). The Regional Geology of Iraq. V.1, Stratigraphy and paleogeography, 445pp. Kassab, I. I. M and Jassim, S. Z. (Editors)S.O.M, Baghdad.

Jaff, R. B. N. (2008). Sequence stratigraphic analysis of the Paleocene successions from selected outcrop and wells in Sulaimani and Kirkuk Governorates, Kurdistan Region, Iraq (Unpublished master thesis), University of Baghdad, University of Sulaimani, 160p.

Jassim, S. Z., Al-Shaibani, S. I., \& Ajina, T. M. (1975). Possible Middle Eocene block movements in the Darbandikhan area, Northern Iraq; 1. Geol. Soc. Iraq. Special Issue, 139-145.

Karim K. H., Koyi, H., Baziany, M. M., \& Hessami, K. (2011). Significance of angular unconformities between Cretaceous and Tertiary strata in the north western segment of the Zagros fold-thrust belt, Kurdistan Region, NE- Iraq. Geological Magazine, Cambridge University Press, 148(6/5), 925-939.

Karim, K. H. (1997). Stratigraphy of Sartaq-Bamo Area from Northeastern Iraq. Retrieved from http://kurdistan-geology.com/?p=384

Karim, K. H. (2004). Basin analysis of Tanjero Formation in Sulaimaniya area, NE-Iraq. (Unpublished doctoral dissertation), University of Sulaimani University, 135p.

Karim, K. H. (2006). Origin of ball and pillow-like structures in Tanjero and Kolosh Formation in Sulaymania are, NE-Iraq. $K A J, 4(1)$.

Karim, K. H. (2010). Modification of the time-expanded stratigraphic column of North East Iraq during Cretaceous and Tertiary,. Published in: Petroleum Geology of Iraq (First Symposium, 21-22april, Baghdad, Abstract book, p4.

Karim, K. H. (2013). New geologic setting of the Bekhme Formation. Journal of Zankoy Sulamani (JZS), 15(3) 23-38.

Karim, K. H., \& Ali, S. S. (2004). Origin of dislocated limestone blocks on the slope side of Baranan (Zirgoez) Homocline: An attempt to outlook the development of western part of Sharazoor Plain. AKJ, 3(1), 5-20.

Karim, K. H., \& Surdashy, A. M. (2005). Paleocurrent analysis of Upper Cretaceous Foreland Basin: A case study for Tanjero Formation in Sulaimaniya area NE-Iraq. Iraqi Journal of Earth Science of Mosul University, 5(1), 30-44.

Karim, K. H., Al-Barzinjy, S. T., \& Ameen, B. M. (2008). History and Geological Setting of Intermontane Basin in the Zagros Fold-Thrust Belt, Kurdistan Region, Iraqi Bulletin of Geology and Mining, 4(1), 21-33.

Karim, K. H., Surdashy, A. M., \& Al-Barzinjy, S. T. (2007). Concurrent and lateral deposition of flysch and molasse in the foreland basin of Upper Cretaceous and Paleocene from NE-Iraq, Kurdistan Region. GRMENA-2. Geologic Conference of Middle East and North Africa, Egypt. Cairo.), 757-769.

Khanaqa, P. A., \& Karim, K. H. (2015) Stratigraphical and Structural Analyses of the Sagrma (Sagerma) Anticline, Sulaimani Area, Iraqi Kurdistan Region, Journal of Geography and Geology, 7(4).

Lawa, F. A. (2004). Sequence stratigraphic analysis of the middle Paleocene-Middle Eocene in the Sulaimani District (Kurdistan Region). (Unpublished doctoral dissertation), University of Sulaimani, Iraq.

Lawa, F. A., \& Ameen, F. A. (2008) Sequence Stratigraphy and Basin Modeling of the Eocene Succession from Kurdistan Region, Northeastern Iraq. AAPG Search and Discovery Article \#90077, GEO 2008 Middle East Conference and Exhibition, Manama, Bahrain

Lawa, F. A., Koyi, H., \& Ibrahim, A. (2013). Tectono-stratigraphic evolution of the NW segment of the Zagros 
Fold - Thrust Belt, Kurdistan, NE Iraq. Journal of Petroleum Geology, 36(1), 75-96

Nabil, Y., Al-Banna, M., Al-Mutwali, M., \& Zaid, A. M. (2012). Paleocene Stratigraphy in Aqra and Bekhme, Areas, Northern Iraq, 228-259, InTech.

Surdashy, A. M, (1988). Lithological, facies and environmental study of Sinjar Formation in selected sections from Sulaimanyia area, Northeast of Iraq, (Unpublished master thesis), University of Salahaddin, 165.

Surdashy, A. M., \& Lawa, F. A. (1993). Stratigraphy and depositional environment of Sinjar Formation in selected sections, NE.Iraq; ZANCO, special issue of proceeding of 2nd Sci. Con. of Salahaddin University, Erbil, 77-110. ( printed in 1999).

\section{Copyrights}

Copyright for this article is retained by the author(s), with first publication rights granted to the journal.

This is an open-access article distributed under the terms and conditions of the Creative Commons Attribution license (http://creativecommons.org/licenses/by/3.0/). 